\title{
Retraction
}

\section{Retracted: Naturally Occurring Xanthones: Chemistry and Biology}

\author{
Journal of Applied Chemistry
}

Received 3 February 2021; Accepted 3 February 2021; Published 15 March 2021

Copyright (C) 2021 Journal of Applied Chemistry. This is an open access article distributed under the Creative Commons Attribution License, which permits unrestricted use, distribution, and reproduction in any medium, provided the original work is properly cited.

Journal of Applied Chemistry has retracted the article titled "Naturally Occurring Xanthones: Chemistry and Biology" [1]. The article was found to contain a substantial amount of overlapping material from previously published articles, including the following sources cited as [2-5]:

(i) Kurt Hostettmann, Hildebert Wagner, "Xanthone glycosides," Phytochemistry, Volume 16, Issue 7, 1977, Pages 821-829, ISSN 0031-9422, doi: 10.1016/ S0031-9422(00)86673-X [2].

(ii) L. M.M. Vieira, A. Kijjoa, Naturally-occurring xanthones: recent developments, Current Medicinal Chemistry, Volume 12, Issue 21, 2005, doi: 10.2174/ 092986705774370682 [3].

(iii) S. R. Jensen, J. Schripsema, Chemotaxonomy and pharmacology of Gentianaceae. In: Lena Struwe, Victor A. Albert (eds.), Gentianaceae, 573-632, January 2001. doi: 10.1017/cbo9780511541865.007 [4].

(iv) Ozlem Demirkiran, (2007) Xanthones in Hypericum: synthesis and biological activities. In: Khan M. T. H. (eds) Bioactive Heterocycles III. Topics in Heterocyclic Chemistry, vol. 9. Springer, Berlin, Heidelberg, Germany, doi: 10.1007/7081_2007_079 [5].

Additionally, 507 words were reproduced from the authors' earlier review article [6], cited as reference 108 in the article.

The article is being retracted due to this overlap, with the agreement of the editorial board. The authors did not respond to these concerns.

\section{References}

[1] S. Negi, V. K. Bisht, P. Singh, M. S. M. Rawat, and G. P. Joshi, "Naturally occurring xanthones: chemistry and biology," Journal of Applied Chemistry, vol. 2013, Article ID 621459, 9 pages, 2013.

[2] H. Kurt and H. Wagner, "Xanthone glycosides," Phytochemistry, vol. 16, no. 7, pp. 821-829, 1977.

[3] L. M. M. Vieira and A. Kijjoa, "Naturally-occurring xanthones: recent developments," Current Medicinal Chemistry, vol. 12, no. 21, 2005.

[4] S. R. Jensen and J. Schripsema, "Chemotaxonomy and pharmacology of Gentianaceae," in Gentianaceae-Systematics and Natural History, V. A. Albert, Ed., Cambridge University Press, Cambridge, UK, 2001.

[5] O. Demirkiran, "Xanthones in Hypericum: synthesis and biological activities," in Bioactive Heterocycles III. Topics in Heterocyclic Chemistry, M. T. H. Khan, Ed., Springer, Berlin, Heidelberg, Germany, 2007.

[6] J. S. Negi, P. Singh, and B. Rawat, "Chemical constituents and biological importance of Swertia: a review," Current Research in Chemistry, vol. 3, pp. 1-15, 2011. 


\title{
Review Article \\ Naturally Occurring Xanthones: Chemistry and Biology
}

\author{
J. S. Negi, ${ }^{1}$ V. K. Bisht, ${ }^{1}$ P. Singh, ${ }^{2}$ M. S. M. Rawat, ${ }^{2}$ and G. P. Joshi ${ }^{2}$ \\ ${ }^{1}$ Herbal Analytical Laboratory, Herbal Research and Development Institute, Mandal, Gopeshwar, Uttarakhand 246401, India \\ ${ }^{2}$ Department of Chemistry, HNB Garhwal University, Srinagar, Garhwal, Uttarakhand 246174, India
}

Correspondence should be addressed to J. S. Negi; negijs@yahoo.com

Received 4 April 2013; Accepted 24 September 2013

Academic Editor: Ming-Jer Lee

Copyright (C) 2013 J. S. Negi et al. This is an open access article distributed under the Creative Commons Attribution License, which permits unrestricted use, distribution, and reproduction in any medium, provided the original work is properly cited.

\begin{abstract}
Xanthones are one of the biggest classes of compounds in natural product chemistry. A number of xanthones have been isolated from natural sources of higher plants, fungi, ferns, and lichens. They have gradually risen to great importance because of their medicinal properties. This review focuses on the types, isolation, characterization, biological applications, and biosynthesis of naturally occurring xanthones isolated so far. Different physicochemical and instrumental methods such as liquid-solid and liquid-liquid extraction, TLC, flash chromatography, column chromatography, IR, ${ }^{1} \mathrm{H}$ NMR and ${ }^{13} \mathrm{C}$ NMR spectroscopy, GLC, HPLC, GC, and LCMS have been widely used for isolation and structural elucidation of xanthones. Hepatoprotective, anticarcinogenic, antileprosy, antimalarial, antioxidant, anticholinergic, mutagenicity, radioprotective, immunomodulatory, antibone resorption, antiparasitic, neuraminidase inhibitory, anticomplement, antibacterial, antifungal, algicidal, anti-HIV, cardioprotective, antitumoral, antidiabetes, antihyperlipidemic, antiatherogenic, anti-inflammatory, antiulcer, antidiabetic, hypolipidemic, analgesic, antiasthmatic, antihistaminic, antiamoebic, diuretic, antidiarrheal, larvicidal, and ovicidal activities have been reported for natural occurring xanthones. To a certain extent, this review provides necessary foundation for further research and development of new medicines.
\end{abstract}

\section{Introduction}

Xanthones are secondary metabolites commonly occurring in higher plant families, fungi, and lichen [1]. Their pharmacological properties have raised great interest. Structures of xanthones are related to that of flavonoids and their chromatographic behaviours are also similar. Flavonoids are frequently encountered in nature, whereas xanthones are found in limited number of families. Xanthones always occur in the families Gentianaceae, Guttiferae, Moraceae, Clusiaceae, and Polygalaceae. Xanthones are sometimes found as the parent polyhydroxylated compounds but most are mono- or polymethyl ethers or are found as glycosides [2]. Unlike iridoids, xanthones are apparently not present in all plant species investigated in the family Gentianaceae. This is documented by the systematic work of Hostettmann et al. [3]. Natural occurrence of 12 xanthones in higher plants and 4 in fungi has been reviewed by Roberts in 1961 and by Dean in 1963 [4, 5]. Gottlieb [6] mentioned the isolation of 60 xanthones from higher plants and 7 from fungi, whereas Carpenter et al. [7] listed 82 xanthones from higher plants.
Gunasekera [8] recorded 183 xanthones from 5 families of tracheophyta. According to Vieira and Kijjoa [9], out of total 515 xanthones, 278 were reported from natural sources. These xanthones have been isolated from 20 families of higher plants (122 species in 44 genera), fungi (19 species), and lichens ( 3 species). In this period, the xanthones from higher plants appear to be associated mainly with the families Clusiaceae (55 species in 12 genera) and Gentianaceae (28 species in 8 genera). Bo and Liu [10] have reviewed separation methods used for pharmacologically active xanthones. Jose Pedraza-Chaverri et al. [11] reviewed the isolated chemical constituents and medicinal properties of C. Garcinia (mangostana). Some of the plants, ferns, and fungus species which contain xanthones are Artocarpus, Anthocleista, Allanblackia, Andrographis, Aspergillus, Bersama, Blackstonia, Calophyllum, Canscora, Centaurium, Chironia, Cratoxylum, Comastoma, Garcinia, Cudrania, Eustoma, Emericella, Frasera, Garcinia, Gentiana, Gentianella, Gentianopsis, Halenia, Hoppea, Hypericum, Ixanthus, Lomatogonium, Mesua, Morinda, Macrocarpaea, Mangrove fungi, Orphium, Peperomia, Pentadesma, Polygala, Penicillium, Phoma, Phomopsis, Rheedia, 
Rhus, Securidaca, Symphonia, Schultesia, Swertia, Tripterospermum, Vismia, Veratrilla, and Xylaria.

\section{Classification}

Xanthones isolated from natural sources are classified into six main groups, namely, simple xanthones, xanthone glycosides, prenylated xanthones, xanthonolignoids, bisxanthones, and miscellaneous xanthones.

2.1. Simple Oxygenated Xanthones. Simple oxygenated xanthones are subdivided according to the degree of oxygenation into non-, mono-, di-, tri-, tetra-, penta-, and hexaoxygenated substances $[9,12,13]$. In these xanthones the substituents are simple hydroxy, methoxy, or methyl groups. About 150 simple oxygenated xanthones have been reported.

2.1.1. Nonoxygenated Simple Xanthones. The nonoxygenated xanthones, namely, methylxanthones (1-,2-,3-,4-methylxanthone), were reported in crude oils from off-shore Norway [14]. This was the first description of xanthones in fossil organic matter. These xanthones might have been generated as diagenetic products, formed by oxidation of xanthenes in the reservoir, or might have originated by biosynthesis from aromatic precursors.

2.1.2. Monooxygenated Xanthones. Besides, six monooxygenated xanthones from Swertia, 2-hydroxyxanthone, 4-hydroxyxanthone, and 2-methoxyxanthone have been isolated from four genera, namely, Calophyllum, Kielmeyera, Mesua, and Ochrocarpus.

2.1.3. Dioxygenated Xanthones. More than fifteen dioxygenated xanthones were reported from plants of the families Clusiaceae and Euphorbiaceae. 1,5-Dihydroxyxanthone, 1,7dihydroxyxanthone, and 2,6-dihydroxyxanthone are found fairly extensively. Other deoxygenated xanthones such as 1-hydroxy-5-methoxyxanthone, 1-hydroxy-7-methoxyxanthone, 2-hydroxy-1-methoxy-xanthone, 3-hydroxy-2-methoxyxanthone, 3-hydroxy-4-methoxyxanthone, 5-hydroxy-1-methoxyxanthone, and 1,2-methylenedioxyxanthone have been reported from eleven plants genera.

2.1.4. Trioxygenated Xanthones. Forty-five trioxygenated xanthones have been reported; out of these fifteen were described as new. Among these, only two natural sulfonated xanthones, namely, 1,3-dihydroxy-5-methoxyxanthone4 -sulfonate and 5-O- $\beta$-D-glucopyranosyl-1,3-dihydroxyxanthone-4-sulfonate, are reported from Hypericum sampsonii. These sulfonated xanthones were found to exhibit significant cytotoxicity against cancer cell line $[15,16]$. 1,3,5-, 1,5,6-, 1,6,7-, and 2,3,4-trihydroxyxanthone, seventeen methyl ethers, and two methylenedioxy derivatives from nine genera have been reported.

2.1.5. Tetraoxygenated Xanthones. Among the 53 tetraoxygenated xanthones identified so far, 21 were found to be new natural products. These xanthones were mainly reported from plants of the families Gentianaceae, Clusiaceae, and Polygalaceae. Interestingly, 7-chloro-1,2,3-trihydroxy-6methoxyxanthone isolated from Polygala vulgaris [17] appeared to be the first chloroxanthone of the family Polygalaceae. This compound exhibited antiproliferative activity against the human intestinal adenocarcinoma cell line. The free hydroxyxanthones are 1,3,5,6-, 1,3,5,7-, and 1,3,6,7-tetrahydroxyxanthone [18].

2.1.6. Pentaoxygenated Xanthones. Twenty-seven pentaoxygenated xanthones have been identified. Four partially methylated pentaoxygenated xanthones, namely, 1,8-dihydroxy-2,3,7-trimethoxyxanthone, 5,6-dihydroxy-1,3,7-trimethoxyxanthone, 1,7-dihydroxy-2,3,8-trimethoxyxanthone, 3,8-dihydroxy-1,2,6-trimethoxyxanthone [19], and 3,7dihydroxy-1,5,6-trimethoxyxanthone, have been isolated from three plants genera.

2.1.7. Hexaoxygenated Xanthones. Two hexaoxygenated xanthones, 8 -hydroxy-1,2,3,4,6-pentamethoxyxanthone $[15,20]$ and 1,8-dihydroxy-2,3,4,6-tetramethoxyxanthone [21], are isolated from two Centaurium species and 3-hydroxy1,2,5,6,7-pentamethoxyxanthone was isolated from the roots of Polygala japonica. The natural occurrence of pentaoxygenated, hexaoxygenated, and dimeric xanthones has been reviewed by Peres and Nagem [22].

2.2. Xanthone Glycosides. Sixty-one naturally occurring glycosylated xanthones, thirty-nine of which are new compounds, have been reported predominantly in the families Gentianaceae and Polygalaceae as C- or O-glycosides. The details of naturally occurring xanthone glycosides have been reviewed [2] and distinction between C-glycosides and Oglycosides has also been made. In C-glycosides, $\mathrm{C}-\mathrm{C}$ bond links the sugar moiety to the xanthone nucleus and they are resistant to acidic and enzymatic hydrolysis whereas the $\mathrm{O}-$ glycosides have typical glycosidic linkage.

2.2.1. C-Glycosides. C-glycosides are rare; thus, only seven $\mathrm{C}$-glycosides were mentioned in Sultanbawa's review [13] and 17 in Al-Hazimi's review [23]. Mangiferin and isomangiferin are the most common C-glycosides. Mangiferin (2,-C- $\beta$-Dglucopyranosyl-1,3,6,7-tetrahydroxyxanthone) is of widespread occurrence in angiosperms and ferns and was first isolated from Mangifera indica [24-26]. An isomer, isomangiferin (4-C- $\beta$-D-glucopyranosyl-1,3,6,7tetrahydroxyxanthone), has been isolated from the aerial parts of Anemarrhena asphodeloides [27]. Homomangiferin (2-C- $\beta$-D-glucopyranosyl-3-methoxy-1,6,7-trihydroxyxanthone) has also been isolated from the bark of Mangifera indica [28]. In 1973, another glycoxanthone (2-C- $\beta$-Dglucopyranosyl-1,3,5,6-tetrahydroxyxanthone) with an oxidation pattern other than that of mangiferin was found in Canscora decussate [29]. Arisawa and Morita [30] have isolated tetraoxygenated xanthone glycoside $2-C-\beta$-Dglucopyranosyl-5-methoxy-1,3,6-trihydroxyxanthone from Iris florentina. 
2.2.2. O-Glycosides. More than 20 xanthone O-glycosides are known. A few are from natural sources, namely, gentiacauloside from Gentiana acaulis, gentioside from G. lutea, and swertianolin from Swertia japonica [31]. Their natural occurrence is restricted to the family Gentianaceae. The first xanthone O-glycoside, norswertianin-1-O-glucosyl-3O-glucoside, was isolated from S. perennis [2]. A tetraoxygenated xanthone O-glycoside (3,7,8-trihydroxyxanthone-1$\mathrm{O}-\beta$-laminaribioside) was isolated from the fern species [32]. 1-Hydroxy-7-methoxy-3-O-primeverosylxanthone [33] and 1-methoxy-5-hydroxyxanthone-3-O-rutinoside [34] have been isolated from Gentiana species and Canscora decussata.

\subsection{Prenylated and Related Xanthones. Among 285 preny-} lated xanthones, 173 were described as new compounds. The occurrence of prenylated xanthones is restricted to the plant species of the family Guttiferae. The major $\mathrm{C}_{5}$ unit of the substituents included the commonly found 3-methylbut-2enyl or isoprenyl group as in isoemericellin and the less frequent 3-hydroxy-3-methylbutyl as in nigrolineaxanthone $\mathrm{P}$ and 1,1-dimethylprop-2-enyl as in globuxanthone, respectively [35-37]. Prenylated xanthones, caloxanthone $\mathrm{O}$ and caloxanthone P, were isolated from Calophyllum inophyllum [38] and polyprenylated xanthones and benzophenones from Garcinia oblongifolia [39].

2.4. Xanthonolignoids. Naturally occurring xanthonolignoids are rare, so only five compounds are known. The first xanthonolignoid was isolated from Kielmeyera species by Castelão Jr. et al. [40]. They also isolated two other xanthonolignoids named Cadensins A and B from Caraipa densiflora. A xanthonolignoid Kielcorin was obtained from Hypericum species [41]. Recently, kielcorin was also isolated from Vismia guaramirangae [42], Kielmeyera variabilis [43], and Hypericum canariensis [44], whereas cadensin C and cadensin D from Vismia guaramirangae and Hypericum canariensis have been reported [45].

2.5. Bisxanthones. A total of twelve bisxanthones, five from higher plants, one from lichen, and six from fungi, have been reported to date. These include jacarelhyperols A and B [46], from the aerial parts of Hypericum japonicum and dimeric xanthone, and globulixanthone $\mathrm{E}$, from the roots of Symphonia globulifera [47]. Three $\mathrm{C}_{2}-\mathrm{C}_{2}$ ' dimeric tetrahydroxyxanthones dicerandrols $\mathrm{A}, \mathrm{B}$, and $\mathrm{C}$, are also isolated from the fungus Phomopsis longicolla [48].

2.6. Miscellaneous. Xanthones with substituents other than those mentioned above are included in this group. Xanthofulvin and vinaxanthone were isolated from Penicillium species [49]. A polycyclic substance (xanthopterin) with the ability to inhibit the HSP47 (heat shock protein) gene expression was isolated from the culture broth of a Streptomyces species [50]. Xantholiptin is a potent inhibitor of collagen production induced by treatment with TGF-b in human dermal fibroblasts. Xanthones have been synthesized by different methods. The elements of synthetic methods such as building blocks,
Diels-Alder reaction, and heterogeneous catalysts have also been reviewed [51].

\section{Methods for Isolation and Characterization of Xanthones}

Plants xanthones are commonly isolated by column chromatography on silica gel using different solvent mixtures with increasing polarity [52-55]. Xanthone glycosides are usually crystallized from $\mathrm{MeOH}$. They may also be separated and identified using TLC [56] and HPLC [57-61] by comparison with authentic samples. The structure of xanthones has been established on the basis of UV, IR, MS, and NMR data $[13,62-$ 72]. Preparative TLC on silica gel using AcOEt, $\mathrm{MeOH}$, and $\mathrm{H}_{2} \mathrm{O}(21: 4: 3)$ as mobile phase has been used in instances of difficult separation. Frequently used solvents in TLC are on polyamide, $\mathrm{MeOH}-\mathrm{H}_{2} \mathrm{O}(9: 1)$ and $\mathrm{MeOH}-\mathrm{H}_{2} \mathrm{O}-\mathrm{AcOH}$ (90:5:5); on cellulose, HOAc (5-30\%); on silica gel, Py$\mathrm{H}_{2} \mathrm{O}-\mathrm{AcOEt}-\mathrm{MeOH}(12: 10: 80: 5)$ and AcOEt-MeOH- $\mathrm{H}_{2} \mathrm{O}$ $(21: 4: 3)$ and chromatoplates are viewed in UV light. In certain cases, spraying with $5 \% \mathrm{KOH}$ in $\mathrm{MeOH}$ or $5 \%$ aqueous $\mathrm{H}_{2} \mathrm{SO}_{4}$ has been advantageous [33]. Polyamide columns are frequently applied for the separation of xanthone glycosides. Purification of xanthones on Sephadex LH20 column has also been carried out [2]. Xanthones are also isolated from resin of Garcinia hanburyi [73] and from the fermentation products of an endophytic fungus Phomopsis [74].

HPLC has been proved as the best technique for separation, identification, and quantification of xanthones. Several HPLC methods have been developed for naturally occurring xanthones using microporous chemically bonded silica gel (Micropak CN column), solvent hexanechloroform $(13: 7, \mathrm{v} / \mathrm{v})$, isooctane- $\mathrm{CHCl}_{3}(3: 17, \mathrm{v} / \mathrm{v})$, or dioxane-dichloromethane $(1: 9)$ detected at $254 \mathrm{~nm}$ by UV detector [60]. Polar aglycones as well as glycosides of xanthones are also resolved on reversed phase column $\left(\mathrm{C}_{8}\right.$ and $\left.\mathrm{C}_{18}\right)$ using acetonitrile-water as mobile phase [75, 76]. High-speed counter current chromatography (HSCCC) and high performance centrifugal partition chromatography (HPCPC) were also used for the separation and isolation of mangiferin and neomangiferin from an extract of Anemarrhena asphodeloides [77] and $\alpha$-mangostins and $\gamma$ mangostins from mangosteen pericarp, respectively [78].

3.1. Ultraviolet Visible Spectroscopy (UV). Ultraviolet visible spectroscopy technique is useful for locating free hydroxyl groups in xanthones. In particular, the $\mathrm{OH}$ group at position 3 is easily detected by addition of $\mathrm{NaOAc}$ which results in a bathochromic shift of the $300-330 \mathrm{~nm}$ bands with increased intensity. Three or four bands of maximum absorption are always found in the region $220-410 \mathrm{~nm}$ and it is noteworthy that all bands show high intensity. Most of the substances show a marked absorption in the $400 \mathrm{~nm}$ regions, which accounts for their yellow colour [79].

3.2. Infrared Spectroscopy (IR). The carbonyl group in xanthones is always easily detectable in IR spectra as a strong band (stretching frequency) in the region of $1657 \mathrm{~cm}^{-1}$ [53]. 
The presence of a hydroxyl group in the 1 or 8 position lowers the frequency to about $1650 \mathrm{~cm}^{-1}$ by hydrogen bonding. Substituents in the 3 or 6 position of the xanthone nucleus may have a marked effect upon the carbonyl stretching frequency [80].

3.3. Proton Nuclear Magnetic Resonance Spectroscopy $\left({ }^{1} \mathrm{H}\right.$ NMR). 1D and 2D-NMR spectra $\left({ }^{1} \mathrm{H},{ }^{13} \mathrm{C}\right.$, DEPT, COSY, TOCSY, HROESY, HSQC, HMBC, and NOESY) have been used for characterization of the xanthones. The ${ }^{1} \mathrm{H}$ NMR spectrum appears predominantly in the range of $0-12 \mathrm{ppm}$ downfield from the reference signal of TMS. The integral of the signals is proportional to the number of protons present. ${ }^{1} \mathrm{H}$ NMR gives information about the substitution pattern on each ring. Acetylated derivatives have been utilised in the structure determination of glycosides [81]. The number and relative position of acetyl and methoxy groups can be determined by observing the shift for the position of absorption for the aromatic protons which occurs upon replacing methoxy group by an acetyl group. Signals between $\delta 2.40-2.50$ are indicative of acetylation at peri-position to the carbonyl group ( 1 or 8 position) since for other positions the acetyl signals fall between $\delta 2.30$ and 2.35. In nonacetylated xanthones the presence of hydrogen bonded $\mathrm{OH}$ at $\delta 12$ 13 also confirms hydroxyl substitution at 1 or 8 . But when these positions are unsubstituted, then absorption for the aromatic protons appears at $\delta 7.70-8.05$ [82]. Tetraoxygenated xanthones, namely, 1,3,7,8- and 1,3,5,8-, showed two metaand two ortho-coupled protons in the ${ }^{1} \mathrm{H}$ NMR spectrum. They can also be distinguished by the fact that the presence for the ortho-coupled proton in the 1,3,7,8- system appears at lower field [83] than that for 1,3,5,8- (bellidifolin) system [84]. The signals of $2^{\prime \prime}$-O-acetyl methyl protons of 8-Cglucosyl flavone acetate are found at higher field than those of corresponding 6-C-glucosyl flavone acetate [85]. In a similar manner, 2-C and 4-C isomeric glycosyl xanthones can be distinguished.

3.4. Carbon Nuclear Magnetic Resonance Spectroscopy $\left({ }^{13} \mathrm{C}\right.$ NMR). The number of signals in the ${ }^{13} \mathrm{C}$ NMR spectrum indicates the number of different types of $\mathrm{C}$ atoms. It gives the information about the total number of the $\mathrm{C}$ atoms present in the molecule. It is particularly diagnostic for determining the sugar linkage in di- or polysaccharides; the signal of the carbon carrying the primary alcohols appears at $\delta 62$ in glucose. This signal is shifted to $\delta 67$ in disaccharides possessing a 16 linkage $[60,61]$. The chemical shift for carbonyl carbon is $\delta 184.5$ when positions 1 and 8 are substituted by hydroxyl groups. But when one of these positions is occupied either by a methoxy or a sugar moiety, the carbonyl signal is shifted upfield by about $4 \mathrm{ppm}$. If both positions are occupied by a methoxy group or sugar moieties, the upfield shift is about $10 \mathrm{ppm}$. When methoxy groups are located in position 1 or 8 , the corresponding absorption appears at $\delta 60-61$, whereas they appear at about $\delta 56$ when the methoxy group is located in the remaining positions on xanthone nucleus [53].

3.5. Mass Spectrometry (MS). Mass spectrometry is also a useful tool in the structure elucidation of xanthone glycosides. Prox [86] established the fragmentation pattern of mangiferin and related C-glycosides. Aritomi and Kawasaki $[27,28]$ obtained satisfactory results using peracetylated derivatives of the same and analogous compounds. In mass spectrum of O-glycosides, no discernible molecular ion peak can be observed, but an important fragment ion peak due to the aglycone moiety appears, followed by further fragmentation. Significant fragment ions from the loss of $\mathrm{OH}, \mathrm{H}_{2} \mathrm{O}$, and $\mathrm{CHO}$ are typical for xanthones and related compounds with a methoxy substituent peri to the carbonyl group [34, 53, 87].

\section{Biological Activities of Xanthones}

Plants belonging to the family Gentianaceae are best known for their bitter taste due to the presence of xanthones and are used in traditional remedies against loss of appetite and fever and are still included in many "tonic" formulations [88]. Some specific activities have been reported for xanthones and iridoids from Gentianaceae. Xanthones (especially mangiferin) are reported to give CNS stimulation $[89,90]$ and have anti-inflammatory activity [12]. For bellidifolin and swerchirin, a strong hypoglycemic activity has been reported [91-93]. A crude extract of Swertia has been reported to display insect repellent activity [94]. The extracts of most of the Swertia species show mutagenic activity [95]. An extract from S. paniculata is used in the Indian System of Medicine as a bitter tonic and in the treatment of some mental disorders [96]. S. hookeri extract is used in the treatment of microbial infections and as a mood elevator [97]. Swertifrancheside isolated from S. franchetiana was found to be potent inhibitor of the DNA polymerase activity of human immunodeficiency virus-1 reverse transcriptase [98]. Naturally occurring xanthones have emerged as an important class of organic compounds in view of their remarkable pharmacological and other biological activities. It has now been observed that a number of plant products which are in regular use as chemotherapeutic agents contain xanthones as active constituents. Mangiferin was the first xanthone to be investigated pharmacologically and has been found to exhibit a broad spectrum of biological activities. It shows monoamine oxidase inhibition, cardiotonic, convulsant, and choleretic activities [29, 89]. Pronounced anti-inflammatory activity has also been observed for mangiferin [99]. Oral and topical compounds containing mangiferin are useful for the treatment of diseases caused by herpes virus. Mangiferin has been found to protect the liver of the rats from high altitude hypoxia. On the other hand, Ghosal and Chaudhuri [100] have observed the opposite CNS depressant effect for xanthone-O-glycosides in mice and rats. The antimalarial drug AYUSH-64 contains S. chirata as one of the ingredients. Xanthones from $S$. chirata are reported to produce CNS depression [29]. The total extract of S. chirata showed significant antifeedant activity against Jute semilooper [101]. Norswertianolin, an O-glycoside, has been reported to produce antitubercular activity. The O-glycosides of $S$. purpurascens are known to produce CNS depression in albino rats and mice [102]. Xanthones of Mammea americana exhibited inhibitory 

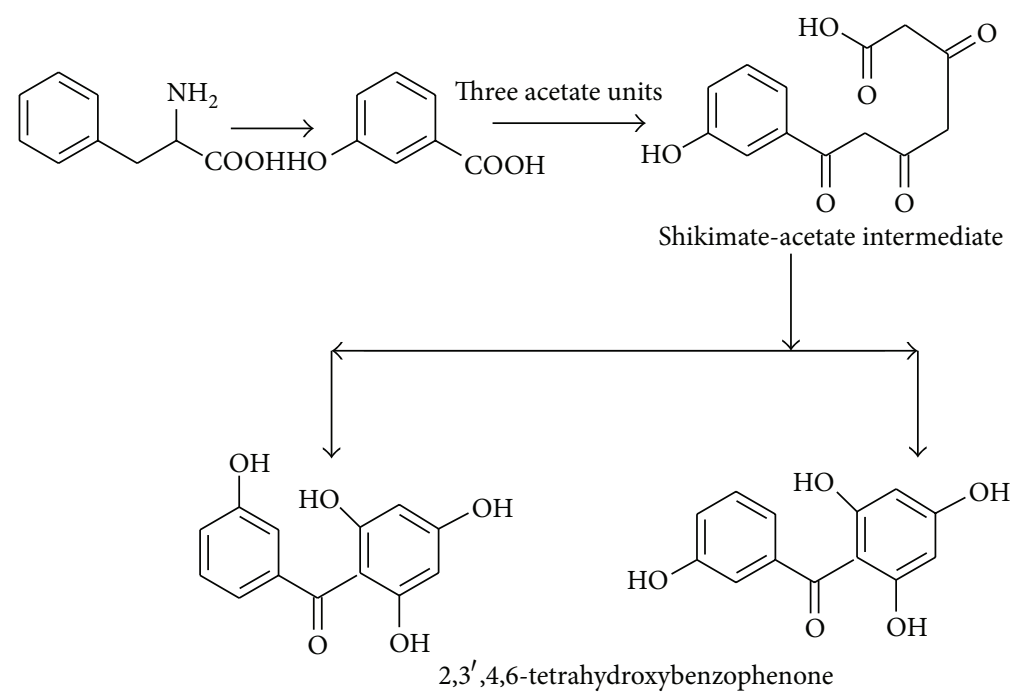<smiles></smiles>

(1) 1,3,5-trihydroxyxanthone

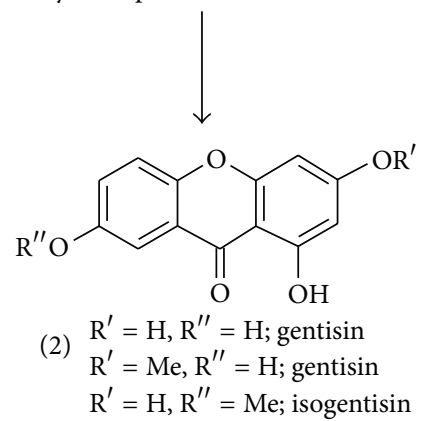

FIGURE 1: Biosynthetic pathways leading to the xanthones (1) and (2).

activity against sarcoma 180 tumor cell [103]. 1,8-Dihydroxy3,5-dimethoxyxanthone (swerchirin), isolated from the hexane fraction from Swertia chirayita, has a very significant blood sugar lowering effect in fasted, fed, glucose loaded, and tolbutamide pretreated albino rats. The $\mathrm{ED}_{50}$ for $40 \%$ glycaemia lowering in CF male albino rats was $23.1 \mathrm{mg} / \mathrm{kg}$ when orally administered [104]. Swertia species have also been investigated for the presence of essential elements [105107]. Xanthones have been reported to display hepatoprotective, antimicrobial, anticarcinogenic, antileprosy, antioxidant, anticholinergic, mutagenicity $[108,109]$, and radioprotective effect [110], immunomodulatory effect [111], antibone resorption [112], and antiparasitic effects [113], neuraminidase inhibitory [114], antimalarial [115], anticomplement [116], antifungal and algicidal [117], and anti-HIV activity [118], and cardioprotective, antitumoral, antibacterial, antidiabetes, antihyperlipidemic, antiatherogenic, immunomodulator, anti-inflammatory, antiulcer, antiviral, antifungal [119], antidiabetic, hypolipidemic [120], analgesic, antiasthmatic, antihistaminic, antiamoebic, diuretic, antidiarrheal, larvicidal, ovicidal, antiprotozoal, antileptospiral, anti-TMV, and anticancer activities [121-124]. Xanthones from S. mussotii were evaluated for their anti-hepatitis B virus activity on HepG 2.2.15 cells line; they exhibited significant activity inhibiting hepatitis $B$ virus DNA replication with $\mathrm{IC}_{50}$ values from $0.01 \mathrm{mM}$ to $0.13 \mathrm{mM}$ [125].

\section{Biosynthesis of Xanthones}

Biosynthetically xanthones are of mixed shikimate and acetate origin (Figure 1). Thus, phenylalanine, which is formed from shikimate, loses two carbon atoms from the side-chain and is oxidized to form $m$-hydroxybenzoic acid. This combines with three units of acetate (via malonate) to give the intermediate. The shikimate-acetate intermediate undergoes ring-closure to give substituted benzophenone, which by an oxidative phenol coupling generates the central ring of the xanthone moiety. This oxidative coupling can take place in two ways depending on the folding of the benzophenone either in the ortho or in the para position to the hydroxyl substituent in the potential B-ring to give 1,3,5-trihydroxyxanthone (1) or the 1,3,7-substituted analogue gentisin (2), respectively. Thus, depending on the orientation of the intermediate, two different hydroxylation patterns can be found. Experimental proof for the overall pathway has been obtained from experiments performed using Gentiana lutea $[126,127]$.

When plants were fed ${ }^{14} \mathrm{C}$-labeled phenylalanine, the label was recovered solely in the B-ring (Figure 1). Conversely, feeding of ${ }^{14} \mathrm{C}$-labeled acetate gave incorporation of the main part in the A-ring. The alternative ring closure to (1) has recently been shown to take place in cultured cells of Centaurium erythraea, where $2,3^{\prime}, 4,6$-tetrahydroxybenzophenone 
is the precursor for 1,3,5-trihydroxyxanthone [128]. Furthermore, in these cell cultures, compound (1) is selectively oxidized by a xanthone 6-hydroxylase to 1,3,5,6tetrahydroxyxanthone [129]. Explored methods for synthesis of simple oxygenated xanthones have been documented by Sousa and Pinto [130].

\section{Conflict of Interests}

The authors declare that there is no conflict of interests regarding the publication of this paper.

\section{Acknowledgments}

The authors are thankful to Director HRDI and Professor M. S. M. Rawat, Dean School of Sciences, HNB Garhwal University, Srinagar, Uttarakhand, India.

\section{References}

[1] M. L. Cardona, I. Fernández, J. R. Pedro, and A. Serrano, "Xanthones from Hypericum reflexum," Phytochemistry, vol. 29, no. 9, pp. 3003-3006, 1990.

[2] K. Hostettmann and I. Miura, "A new Xanthone diglucoside from Swertia perennis L.," Helvetica Chimica Acta, vol. 60, pp. 262-264, 1977.

[3] K. M. Hostettmann, K. Hostettmann, and O. Sticher, "Xanthones, flavones and secoiridoids of american Gentiana species," Phytochemistry, vol. 20, no. 3, pp. 443-446, 1981.

[4] J. C. Roberts, "Naturally occurring xanthones," Chemical Reviews, vol. 61, no. 6, pp. 591-605, 1961.

[5] F. M. Dean, Naturally Occurring Oxygen Ring Compounds, Butterworth, London, UK, 1963.

[6] O. R. Gottlieb, "Biogenetic proposals regarding aucuparins and xanthones," Phytochemistry, vol. 7, no. 3, pp. 411-421, 1968.

[7] I. Carpenter, H. D. Locksley, and F. Scheinmann, "Xanthones in higher plants: biogenetic proposals and a chemotaxonomic survey," Phytochemistry, vol. 8, no. 10, pp. 2013-2025, 1969.

[8] S. P. Gunasekera, University of Sri Lanka, Peradeniya Campus, Peradeniya, Sri Lanka, 1976.

[9] L. M. M. Vieira and A. Kijjoa, "Naturally-occurring xanthones: recent developments," Current Medicinal Chemistry, vol. 12, no. 21, pp. 2413-2446, 2005.

[10] T. Bo and H. Liu, "Separation methods for pharmacologically active xanthones," Journal of Chromatography B, vol. 812, no. 12, pp. 165-174, 2004.

[11] J. Pedraza-Chaverri, N. Cárdenas-Rodríguez, M. OrozcoIbarra, and J. M. Pérez-Rojas, "Medicinal properties of mangosteen (Garcinia mangostana)," Food and Chemical Toxicology, vol. 46, no. 10, pp. 3227-3239, 2008.

[12] S. Mandal, P. C. Das, and P. C. Joshi, "Naturally occuring xanthones from terrestrial flora," Journal of Indian Chemical Society, vol. 69, pp. 611-636, 1992.

[13] M. U. S. Sultanbawa, "Xanthonoids of tropical plants," Tetrahedron, vol. 36, no. 11, pp. 1465-1506, 1980.

[14] T. B. P. Oldenburg, H. Wilkes, B. Horsfield, A. C. T. Van Duin, D. Stoddart, and A. Wilhelms, "Xanthones-novel aromatic oxygen-containing compounds in crude oils," Organic Geochemistry, vol. 33, no. 5, pp. 595-609, 2002.
[15] T. Janković, D. Krstić, K. Šavikin-Fodulović, N. Menković, and D. Grubišić, "Xanthones and secoiridoids from hairy root cultures of Centaurium erythraea and C. pulchellum," Planta Medica, vol. 68, no. 10, pp. 944-946, 2002.

[16] M.-J. Don, Y.-J. Huang, R.-L. Huang, and Y.-L. Lin, "New phenolic principles from Hypericum sampsonii," Chemical and Pharmaceutical Bulletin, vol. 52, no. 7, pp. 866-869, 2004.

[17] S. Dall'Acqua, G. Innocenti, G. Viola, A. Piovan, R. Caniato, and E. M. Cappelletti, "Cytotoxic compounds from Polygala vulgaris," Chemical and Pharmaceutical Bulletin, vol. 50, no. 11, pp. 1499-1501, 2002.

[18] Y. Chen, G. K. Wang, C. Wu, and M. J. Qin, "Chemical constituents of Gentiana rhodantha," Zhongguo Zhong Yao Za Zhi, vol. 38, no. 3, pp. 362-365, 2013.

[19] Q.-C. Xue, C.-J. Li, L. Zuo, J.-Z. Yang, and D.-M. Zhang, "Three new xanthones from the roots of Polygala japonica houtt," Journal of Asian Natural Products Research, vol. 11, no. 5, pp. 465-469, 2009.

[20] P. Valentão, P. B. Andrade, E. Silva et al., "Methoxylated xanthones in the quality control of small centaury (Centaurium erythraea) flowering tops," Journal of Agricultural and Food Chemistry, vol. 50, no. 3, pp. 460-463, 2002.

[21] D. Krstic, T. Jankovic, K. Savikin-Fodulovic, N. Menkovic, and A. Grubisic, "Secoiridoids and xanthones in the shoots and roots of Centaurium pulchellumcultured in-vitro," In Vitro Cellular and Developmental Biology, vol. 39, pp. 203-207, 2003.

[22] V. Peres and T. J. Nagem, "Naturally occurring pentaoxygenated, hexaoxygenated and dimeric xanthones: a literature survey," Quimica Nova, vol. 20, no. 4, pp. 388-397, 1997.

[23] H. M. G. Al-Hazimi and G. A. Miana, "Naturally occuring xanthones in higher plants and ferns," Journal of the Chemical Society of Pakistan, vol. 12, no. 2, pp. 174-188, 1990.

[24] S. Iseda, "Isolation of 1,3,6,7-tetrahydroxyxanthone and the skeletal structure of Mangiferin," Bulletin of the Chemical Society of Japan, vol. 30, pp. 625-629, 1957.

[25] L. J. Haynes and D. R. Taylor, " $C$-glycosyl compounds. Part V. Mangiferin; the nuclear magnetic resonance spectra of xanthones," Journal of the Chemical Society C, pp. 1685-1687, 1966.

[26] V. K. Bhatia, J. D. Ramanathan, and T. R. Seshadri, "Constitution of mangiferin," Tetrahedron, vol. 23, no. 3, pp. 1363-1368, 1967.

[27] M. Aritomi and T. Kawasaki, "A New xanthone C-glucoside, position isomer of Mangiferin, from Anemarrhena asphodeloides Bunge," Chemical and Pharmaceutical Bullelin, vol. 18, pp. 2327-2333, 1970.

[28] M. Aritomi and T. Kawasaki, "A Mangiferin monomethyl ether from Mangifera indica L.," Chemical and Pharmaceutical Bullelin, vol. 18, pp. 2224-2234, 1970.

[29] S. Ghosal and R. K. Chaudhuri, "New tetraoxygenated xanthones of Canscora decussata," Phytochemistry, vol. 12, no. 8, pp. 2035-2038, 1973.

[30] M. Arisawa and N. Morita, "Studies on constituents of genus Iris. VII. The constituents of Iris unguicularis POIR. (I)," Chemical and Pharmaceutical Bulletin, vol. 24, no. 4, pp. 815817, 1976.

[31] V. Plouvier, J. Massicot, and P. Rivaille, "On gentiacauleine, a new tetra-substituted xanthone, aglycone of gentiacauloside of Gentiana acaulis L," Comptes Rendus Hebdomadaires des Seances de l'Academie des Sciences D, vol. 264, no. 9, pp. 1219$1222,1967$. 
[32] F. Imperato, "A xanthone-O-glycoside from Asplenium adiantum-nigrum," Phytochemistry, vol. 19, no. 9, pp. 20302031, 1980.

[33] A. M. Verney and A. M. Debelmas, "Xanthones of Gentiana lutea, G. purpurea, G. punctata, G. pannonica," Annales Pharmaceutiques Francaises, vol. 31, pp. 415-420, 1973.

[34] S. Ghosal, R. B. P. S. Chauhan, K. Biswas, and R. K. Chaudhuri, "New 1,3,5-trioxygenated xanthones in Canscora decussata," Phytochemistry, vol. 15, no. 6, pp. 1041-1043, 1976.

[35] G. Bringmann, G. Lang, S. Steffens, E. Günther, and K. Schaumann, "Evariquinone, isoemericellin, and stromemycin from a sponge derived strain of the fungus Emericella variecolor," Phytochemistry, vol. 63, no. 4, pp. 437-443, 2003.

[36] L. H. D. Nguyen and L. J. Harrison, "Xanthones and triterpenoids from the bark of Garcinia vilersiana," Phytochemistry, vol. 53, no. 1, pp. 111-114, 2000.

[37] V. Rukachaisirikul, M. Kamkaew, D. Sukavisit, S. Phongpaichit, P. Sawangchote, and W. C. Taylor, "Antibacterial Xanthones from the Leaves of Garcinia nigrolineata," Journal of Natural Products, vol. 66, no. 12, pp. 1531-1535, 2003.

[38] H.-F. Dai, Y.-B. Zeng, Q. Xiao, Z. Han, Y.-X. Zhao, and W.-L. Mei, "Caloxanthones $\mathrm{O}$ and $\mathrm{P}$ : two new prenylated xanthones from Calophyllum inophyllum," Molecules, vol. 15, no. 2, pp. 606612, 2010.

[39] W. G. Shan, T. S. Lin, H. N. Yu, Y. Chen, and Z. J. Zhan, "Polyprenylated Xanthones and Benzophenones from the Bark of Garcinia oblongifolia," Helvetica Chimica Acta, vol. 95, no. 8, pp. 1442-1448, 2012.

[40] J. F. Castelão Jr., O. R. Gottlieb, R. A. De Lima, A. A. L. Mesquita, H. E. Gottliebb, and E. Wenkert, "Xanthonolignoids from Kielmeyera and Caraipa species-13C NMR spectroscopy of xanthones," Phytochemistry, vol. 16, no. 6, pp. 735-740, 1977.

[41] H. Nielsen and P. Arends, "Structure of the xanthonolignoid kielcorin," Phytochemistry, vol. 17, no. 11, pp. 2040-2041, 1978.

[42] F. D. Monache, M. M. Mac-Quhae, G. D. Monache, G. B. M. Bettolo, and R. A. De Lima, "Xanthones, xanthonolignoids and other constituents of the roots of Vismia guaramirangae," Phytochemistry, vol. 22, no. 1, pp. 227-232, 1983.

[43] L. Pinheiro, C. V. Nakamura, B. P. Dias Filho, A. G. Ferreira, M. C. M. Young, and D. A. Garcia Cortez, "Antibacterial Xanthones from Kielmeyera variabilis Mart. (Clusiaceae)," Memorias do Instituto Oswaldo Cruz, vol. 98, no. 4, pp. 549-552, 2003.

[44] M. L. Cardona, M. I. Fernández, J. R. Pedro, E. Seoane, and R. Vidal, "Additional new xanthones and xanthonolignoids from Hypericum canariensis," Journal of Natural Products, vol. 49, no. 1, pp. 95-100, 1986.

[45] G. G. Nikolaeva, V. I. Glyzin, M. S. Mladentseva, V. I. Sheichenko, and A. V. Patudin, "Xanthones of Gentiana lutea," Chemistry of Natural Compounds, vol. 19, no. 1, pp. 106-107, 1983.

[46] K. Ishiguro, S. Nagata, H. Oku, and Y. Masae, "Bisxanthones from Hypericum japonicum: inhibitors of PAF-induced hypotension," Planta Medica, vol. 68, no. 3, pp. 258-261, 2002.

[47] A. E. Nkengfack, P. Mkounga, M. Meyer, Z. T. Fomum, and B. Bodo, "Globulixanthones C, D and E: three prenylated xanthones with antimicrobial properties from the root bark of Symphonia globulifera," Phytochemistry, vol. 61, no. 2, pp. 181187, 2002.

[48] M. M. Wagenaar and J. Clardy, "Dicerandrols, new antibiotic and cytotoxic dimers produced by the fungus Phomopsis longicolla isolated from an endangered mint," Journal of Natural Products, vol. 64, no. 8, pp. 1006-1009, 2001.
[49] K. Kumagai, N. Hosotani, K. Kikuchi, T. Kimura, and I. Saji, "Xanthofulvin, a novel semaphorin inhibitor produced by a strain of Penicillium," The Journal of Antibiotics, vol. 56, no. 7, pp. 610-616, 2003.

[50] Y. Terui, C. Yiwen, L. Jun-Ying et al., "Xantholipin, a novel inhibitor of HSP47 gene expression produced by Streptomyces sp," Tetrahedron Letters, vol. 44, no. 29, pp. 5427-5430, 2003.

[51] C. Yang, M. A. Li, W. E. I. Zhen-ping, H. A. N. Feng, and G. A. O. Jing, "Advances in isolation and synthesis of xanthone derivatives," Chinese Herbal Medicines, vol. 4, no. 2, pp. 87-102, 2012.

[52] J. B. Harbirbe, Phytochemical Methods, Chapman and Hall, London, UK, 1973.

[53] O. Purev, K. Oyun, G. Odontuya et al., "Isolation and structure elucidation of two new xanthones from Gentiana azurium Bunge (Fam. Gentianaceae)," Zeitschrift fur Naturforschung B, vol. 57, no. 3, pp. 331-334, 2002.

[54] A. Khan, M. Rahman, and S. Islam, "Isolation and bioactivity of a xanthone glycoside from Peperomia pellucida," Life Sciences and Medicine Research, pp. 1-15, 2010.

[55] V. K. Dua, V. P. Ojha, R. Roy et al., "Anti-malarial activity of some xanthones isolated from the roots of Andrographis paniculata," Journal of Ethnopharmacology, vol. 95, no. 2-3, pp. 247-251, 2004.

[56] H. M. Chawla, S. S. Chibber, and U. Khera, "Separation and identification of some hydroxyxanthones by thin-layer chromatography," Journal of Chromatography A, vol. 111, no. 1, pp. 246-247, 1975.

[57] S. Suryawanshi, N. Mehrotra, R. K. Asthana, and R. C. Gupta, "Liquid chromatography/tandem mass spectrometric study and analysis of xanthone and secoiridoid glycoside composition of Swertia chirata, a potent antidiabetic," Rapid Communications in Mass Spectrometry, vol. 20, no. 24, pp. 3761-3768, 2006.

[58] Y. Song, F. Hu, P. Lin, Y. Lu, and Z. Shi, "Determination of xanthones in Swertia mussotii and Swertia franchetiana by high performance liquid chromatography," Chinese Journal of Chromatography, vol. 22, no. 1, pp. 51-53, 2004.

[59] J.-S. Zhang, X.-M. Wang, X.-H. Dong, H.-Y. Yang, and G.-P. Li, "Studies on chemical constituents of Swertia mussotii," Zhong Yao Cai, vol. 32, no. 4, pp. 511-514, 2009.

[60] J. S. Negi and P. Singh, "HPLC fingerprinting of highly demanding medicinal plant Swertia: an overview," International Journal of Medicinal and Aromatic Plants, vol. 1, no. 3, pp. 333-337, 2011.

[61] J. S. Negi, P. Singh, G. J. Pant, and M. S. M. Rawat, "RP-HPLC analysis and antidiabetic activity of Swertia paniculata," Natural Product Communications, vol. 5, no. 6, pp. 907-910, 2010.

[62] R. R. Sun, F. P. Miao, J. Zhang, G. Wang, X. L. Yin, and N. Y. Ji, "Three new xanthone derivatives from an algicolous isolate of Aspergillus wentii," Magnetic Resonance in Chemistry, vol. 51, no. 1, pp. 65-68, 2013.

[63] H. H. F. Koolen, L. S. Menezes, M. P. Souza et al., "Talaroxanthone, a novel xanthone dimer from the endophytic fungus Talaromyces sp. associated with Duguetia stelechanthan (Diels) R. E. Fries," Journal of the Brazilian Chemical Society, vol. 24, no. 5, pp. 880-883, 2013.

[64] A. K. Chakravarty, T. Sarkar, K. Masuda et al., "Structure and synthesis of glycoborine, a new carbazole alkaloid from the roots of Glycosmis arborea: a note on the structure of glycozolicine," Indian Journal of Chemistry B, vol. 40, no. 6, pp. 484-489, 2001.

[65] S. Mandal and A. Chatterjee, Seminar on Research in Ayurveda and Siddha, CCRAS, New Delhi, India, 1994. 
[66] A. K. Chakravarty, S. Mukhopadhyay, S. K. Moitra, and B. Das, "(-)-Syringaresinol, a hepatoprotective agent and other constituents from Swertia chirata," Indian Journal of Chemistry, vol. 33, pp. 405-408, 1994.

[67] K. S. Khetwal and R. S. Bisht, "A xanthone glycoside from Swertia speciosa," Phytochemistry, vol. 27, no. 6, pp. 1910-1911, 1988.

[68] D. L. Verma and K. S. Khetwal, "Phenolics in the roots of Swertia paniculata Wall," Science and Culture, vol. 51, pp. 305-306, 1985.

[69] M. Kikuchi and M. Kikuchi, "Studies on the constituents of Swertia japonica MAKINO I. On the structures of new secoiridoid diglycosides," Chemical and Pharmaceutical Bulletin, vol. 52, no. 10, pp. 1210-1214, 2004.

[70] H. Yang, C. Ding, Y. Duan, and J. Liu, "Variation of active constituents of an important Tibet folk medicine Swertia mussotii Franch. (Gentianaceae) between artificially cultivated and naturally distributed," Journal of Ethnopharmacology, vol. 98, no. 1-2, pp. 31-35, 2005.

[71] S.-S. Wang, W.-J. Zhao, X.-W. Han, and X.-M. Liang, "Two new iridoid glycosides from the Tibetan folk medicine Swertia franchetiana," Chemical and Pharmaceutical Bulletin, vol. 53, no. 6, pp. 674-676, 2005.

[72] H. Hajimehdipour, Y. Amanzadeh, S. E. Sadat Ebrahimi, and V. Mozaffarian, "Three tetraoxygenated xanthones from Swertia longifolia," Pharmaceutical Biology, vol. 41, no. 7, pp. 497-499, 2003.

[73] Y. X. Deng, T. Guo, Z. Y. Shao, H. Xie, and S. L. Pan, "Three new xanthones from the resin of Garcinia hanburyi," Planta Medica, vol. 79, no. 9, pp. 792-796, 2013.

[74] H. Y. Yang, Y. H. Gao, D. Y. Niu et al., "Xanthone derivatives from the fermentation products of an endophytic fungus Phomopsis sp," Fitoterapia, vol. S0367-326X, no. 13, pp. 0023900246, 2013.

[75] A. Aberham, S. Schwaiger, H. Stuppner, and M. Ganzera, "Quantitative analysis of iridoids, secoiridoids, xanthones and xanthone glycosides in Gentiana lutea L. roots by RP-HPLC and LC-MS," Journal of Pharmaceutical and Biomedical Analysis, vol. 45, no. 3, pp. 437-442, 2007.

[76] R. Dai, J. Gao, and K. Bi, "High-performance liquid chromatographic method for the determination and pharmacokinetic study of mangiferin in plasma of rats having taken the traditional Chinese medicinal preparation Zi-Shen Pill," Journal of Chromatographic Science, vol. 42, no. 2, pp. 88-90, 2004.

[77] T. T. Zhou, Z. Y. Zhu, C. Wang et al., "On-line purity monitoring in high-speed counter-current chromatography: application of HSCCC-HPLC-DAD for the preparation of 5-HMF, neomangiferin and mangiferin from Anemarrhena asphodeloides Bunge," Journal of Pharmaceutical and Biomedical Analysis, vol. 44, no. 1, pp. 96-100, 2007.

[78] Y. Shan and W. Zhang, "Preparative separation of major xanthones from mangosteen pericarp using highperformance centrifugal partition chromatography," Journal of Separation Science, vol. 33, no. 9, pp. 1274-1278, 2010.

[79] K. S. Van and B. Nessler, "Ueber einige oxyxanthone," Chemische Berichte, vol. 24, pp. 3980-3984, 1891.

[80] W. E. Whitman and L. A. Wiles, "The polarographic reduction of xanthone and methoxyxanthones," Journal of Chemical Society, pp. 3016-3019, 1956.

[81] D. Barraclough, H. D. Locksley, F. Scheinmann, M. Taveira Magalhaes, and O. R. Gottlieb, "Applications of proton magnetic resonance spectroscopy in the structural investigation of xanthones," Journal of the Chemical Society B, pp. 603-612, 1970.
[82] M. Kaldas, K. Hostettmann, and A. Jacot-Guillarmod, "Contribution à la phytochimie du genre Gentiana IX. Etude de composés flavoniques et xanthoniques dans les feuilles de Gentiana campestris L. 1ère communication," Helvetica Chimica Acta, vol. 57, pp. 2557-2561, 1974.

[83] K. Hostettmann, R. Tabacchi, and A. Jacot-Guillarmod, “Contribution à la phytochimie du genre Gentiana, VI. Etude des xanthones dans les feuilles de Gentiana bavarica L." Helvetica Chimica Acta, vol. 57, pp. 294-301, 1974.

[84] B. Gentili and R. M. Horowitz, "Flavonoids of Citrus. IX. Some new c-glycosylflavones and a nuclear magnetic resonance method for differentiating 6- and 8-c-glycosyl isomers," Journal of Organic Chemistry, vol. 33, no. 4, pp. 1571-1577, 1968.

[85] D. K. Holdsworth, "A method to differentiate isomeric Cglucosyl chromones, isoflavones and xanthones," Phytochemistry, vol. 12, no. 8, pp. 2011-2015, 1973.

[86] A. Prox, "Massenspektrometrische untersuchung einiger natürlicher C-glukosyl-verbindungen," Tetrahedron, vol. 24, no. 9, pp. 3697-3715, 1968.

[87] P. Arends, P. Helboe, and Moller, "Mass spectrometry of xanthones-I: the electron-impact-induced fragmentation of xanthone, monohydroxy and monomethoxyxanthones," Journal of Organic Mass Spectrometry, vol. 7, pp. 667-681, 1998.

[88] B. Martindale, The Extra Pharmacopoeia, The Pharmaceutical Press, London, UK, 28th edition, 1982.

[89] S. K. Bhattacharya, S. Ghosal, R. K. Chaudhuri, and A. K. Sanyal, "Canscora decussata (Gentianaceae) xanthones. 3. Pharmacological studies," Journal of Pharmaceutical Sciences, vol. 61, no. 11, pp. 1838-1840, 1972.

[90] C. N. Lin, M. I. Chung, M. Arisawa, M. Shimizu, and N. Morita, "The constituents of Tripterospermum taiwanense Satake var. alpinum Satake and pharmacological activity of some xanthone derivatives," Shoyakugaku Zasshi, vol. 38, pp. 80-82, 1984.

[91] A. M. Saxena, M. B. Bajpai, P. S. R. Murthy, and S. K. Mukherjee, "Mechanism of blood sugar lowering by a swerchirincontaining hexane fraction (SWI) of Swertia chirayita," Indian Journal of Experimental Biology, vol. 31, no. 2, pp. 178-181, 1993.

[92] P. Basnet, S. Kadota, T. Namba, and M. Shimizu, "The hypoglycaemic activity of Swertia japonica extract in streptozotocin induced hyperglycaemic rats," Phytotherapy Research, vol. 8, no. 1, pp. 55-57, 1994.

[93] P. Basnet, S. Kadota, M. Shimizu, Y. Takata, M. Kobayashi, and T. Namba, "Bellidifolin stimulates glucose uptake in rat 1 fibroblasts and ameliorates hyperglycemia in streptozotocin (STZ)-induced diabetic rats," Planta Medica, vol. 61, no. 5, pp. 402-405, 1995.

[94] T. Okada, “Insect repellant," Japan. Patent 7875, 327, (Chemical Abstract no. 89: 192516, (1978)), 1977.

[95] I. Morimoto, F. Watanabe, and T. Osawa, "Mutagenicity screening of crude drugs with Bacillus subtilis rec-assay and Salmonella/microsome reversion assay," Mutation Research, vol. 97, no. 2, pp. 81-102, 1982.

[96] A. Prakash, P. C. Basumatary, S. Ghosal, and S. S. Handa, "Chemical constituents of Swertia paniculata," Planta Medica, vol. 45, no. 1, pp. 61-62, 1982.

[97] S. Ghosal, K. Biswas, and D. K. Jaiswal, "Xanthone and flavonol constituents of Swertia hookeri," Phytochemistry, vol. 19, no. 1, pp. 123-126, 1980.

[98] T. Pengsuparp, L. Cai, H. Constant et al., "Mechanistic evaluation of new plant-derived compounds that inhibit HIV-1 reverse transcriptase," Journal of Natural Products, vol. 58, no. 7, pp. 1024-1031, 1995. 
[99] P. C. Das, S. Sarkar, A. Das et al., Proceeding of the 5th ISHS International Symposium on Medicinal, Aromatic and Spice Plants, Darjeeling, India, 1985.

[100] S. Ghosal and R. K. Chaudhuri, "Chemical constituents of gentianaceae XVI: antitubercular activity of xanthones of Canscora decussata Schult," Journal of Pharmaceutical Sciences, vol. 64, no. 5, pp. 888-889, 1975.

[101] R. N. Mullick, P. C. Das, and S. M. Chatterji, "Antifeeding properties of Swerita chirata against jute semilooper (Anomis sabulifera Guen)," Current Science, vol. 54, pp. 1110-1112, 1985.

[102] S. Ghosal, P. V. Sharma, and R. K. Chaudhuri, "Chemical constituents of gentianaceae $\mathrm{X}$ : xanthone $\mathrm{O}$ glucosides of Swertia purpurascens Wall," Journal of Pharmaceutical Sciences, vol. 63, no. 8, pp. 1286-1290, 1974.

[103] R. A. Finnegan, K. E. Merkel, and J. K. Patel, "Constituents of Mammea americana L. XII. Biological data for xanthones and benzophenones," Journal of Pharmaceutical Sciences, vol. 62, no. 3, pp. 483-485, 1973.

[104] M. B. Bajpai, R. K. Asthana, N. K. Sharma, S. K. Chatterjee, and S. K. Mukherjee, "Hypoglycemic effect of swerchirin from the hexane fraction of Swertia chirayita," Planta Medica, vol. 57, no. 2, pp. 102-104, 1991.

[105] J. S. Negi, P. Singh, G. J. Nee Pant, and M. S. M. Rawat, "Study on the variations of mineral elements in Swertia speciosa (G. Don)," Biological Trace Element Research, vol. 138, no. 1-3, pp. 300-306, 2010.

[106] J. S. Negi, "Evaluation of trace element contents in Swertia paniculata Wall," Natural Product Research, vol. 26, no. 1, pp. 7276, 2012.

[107] J. S. Negi, P. Singh, M. S. M. Rawat, and G. J. Pant, "Study on the trace elements in Swertia chirayita (Roxb.) H. Karsten," Biological Trace Element Research, vol. 133, no. 3, pp. 350-356, 2010.

[108] J. S. Negi, P. Singh, and B. Rawat, "Chemical constituents and biological importance of Swertia: a review," Current Research in Chemistry, vol. 3, no. 1, pp. 1-15, 2011.

[109] C. T. Luo, S. S. Mao, F. L. Liu et al., "Antioxidant xanthones from Swertia mussotii, a high altitude plant," Fitoterapia, vol. S0367326X, no. 13, pp. 00229-00233, 2013.

[110] G. C. Jagetia and V. A. Venkatesha, "Mangiferin, a glucosylxanthone, protects against the radiation-induced micronuclei formation in the cultured human peripheral blood lymphocytes," International Congress Series, vol. 1276, pp. 195-196, 2005.

[111] J. Leiro, J. A. Arranz, M. Yáñez, F. M. Ubeira, M. L. Sanmartín, and F. Orallo, "Expression profiles of genes involved in the mouse nuclear factor-kappa B signal transduction pathway are modulated by mangiferin," International Immunopharmacology, vol. 4, no. 6, pp. 763-778, 2004.

[112] H. Li, T. Miyahara, Y. Tezuka et al., "The effect of Kampo formulae on bone resorption in vitro and in vivo. I. Active constituents of Tsu-kan-gan," Biological and Pharmaceutical Bulletin, vol. 21, no. 12, pp. 1322-1326, 1998.

[113] S. Perrucci, G. Fichi, C. Buggiani, G. Rossi, and G. Flamini, "Efficacy of mangiferin against Cryptosporidium parvum in a neonatal mouse model," Parasitology Research, vol. 99, no. 2, pp. 184-188, 2006.

[114] H. W. Ryu, M. J. Curtis-Long, S. Jung et al., "Xanthones with neuraminidase inhibitory activity from the seedcases of Garcinia mangostana," Bioorganic and Medicinal Chemistry, vol. 18, no. 17, pp. 6258-6264, 2010.
[115] M. V. Ignatushchenko, R. W. Winter, and M. Riscoe, "Xanthones as antimalarial agents: sage specificity," The American Journal of Tropical Medicine and Hygiene, vol. 62, no. 1, pp. 77-81, 2000.

[116] G.-H. Quan, S.-R. Oh, J.-H. Kim, H.-K. Lee, A. D. Kinghorn, and Y.-W. Chin, "Xanthone constituents of the fruits of Garcinia mangostana with anticomplement activity," Phytotherapy Research, vol. 24, no. 10, pp. 1575-1577, 2010.

[117] F. M. Tala, K. Krohn, H. Hussain et al., "Laurentixanthone C: a new antifungal and algicidal xanthone from stem bark of Vismia laurentii," Zeitschrift fur Naturforschung B, vol. 62, no. 4, pp. 565-568, 2007.

[118] A. Groweiss, J. H. Cardellina II, and M. R. Boyd, "HIVinhibitory prenylated xanthones and flavones from Maclura tinctoria," Journal of Natural Products, vol. 63, no. 11, pp. 1537$1539,2000$.

[119] M. M. M. Pinto, M. E. Sousa, and M. S. J. Nascimento, "Xanthone derivatives: new insights in biological activities," Current Medicinal Chemistry, vol. 12, no. 21, pp. 2517-2538, 2005.

[120] B. Dineshkumar, A. Mitra, and M. Manjunatha, "Studies on the anti-diabetic and hypolipidemic potentials of mangiferin (xanthone glucoside) in streptozotocin-induced type 1 and type 2 diabetic model rats," International Journal of Advances in Pharmaceutical Sciences, vol. 1, no. 1, pp. 75-85, 2010.

[121] T. Shan, Q. Ma, K. Guo et al., "Xanthones from mangosteen extracts as natural chemopreventive agents: potential anticancer drugs," Current Molecular Medicine, vol. 11, no. 8, pp. 666-677, 2011.

[122] W. Seesom, A. Jaratrungtawee, S. Suksumran et al., "Antileptospiral activity of xanthones from Garcinia mangostana and synergy of gamma-mangostin with penicillin G," BMC Complementary and Alternative Medicine, vol. 13, no. 1, p. 182, 2013.

[123] S. M. Al-Massarani, A. A. El Gamal, N. M. Al-Musayeib et al., "Phytochemical, antimicrobial and antiprotozoal evaluation of Garcinia mangostana pericarp and a-mangostin, its major xanthone derivative," Molecules, vol. 18, no. 9, pp. 10599-10608, 2013.

[124] Y. P. Wu, W. Zhao, Z. Y. Xia et al., "Three novel xanthones from Garcinia paucinervis and their anti-TMV activity," Molecules, vol. 18, no. 8, pp. 9663-9669, 2013.

[125] T. W. Cao, C. A. Geng, Y. B. Ma et al., "Xanthones with antihepatitis B virus activity from Swertia mussotii," Planta Medica, vol. 79, no. 8, pp. 697-700, 2013.

[126] J. E. Atkinson, P. Gupta, and J. R. Lewis, "Benzophenone participation in xanthone biosynthesis (Gentianaceae)," Chemical Communications, no. 22, pp. 1386-1387, 1968.

[127] P. Gupta and J. R. Lewis, "Biogenesis of xanthones in Gentiana lutea," Journal of the Chemical Society C, pp. 629-631, 1971.

[128] S. Peters, W. Schmidt, and L. Beerhues, "Regioselective oxidative phenol couplings of 2,3,4,6-tetrahydroxybenzophenone in cell cultures of Centaurium erythraea RAFN and Hypericum androsaemum L," Planta, vol. 204, no. 1, pp. 64-69, 1998.

[129] W. Schmidt, S. Peters, and L. Beerhues, "Xanthone 6hydroxylase from cell cultures of Centaurium erythraea RAFN and Hypericum androsaemum L," Phytochemistry, vol. 53, no. 4, pp. 427-431, 2000.

[130] M. E. Sousa and M. M. M. Pinto, "Synthesis of xanthones: an overview," Current Medicinal Chemistry, vol. 12, no. 21, pp. 2447-2479, 2005. 

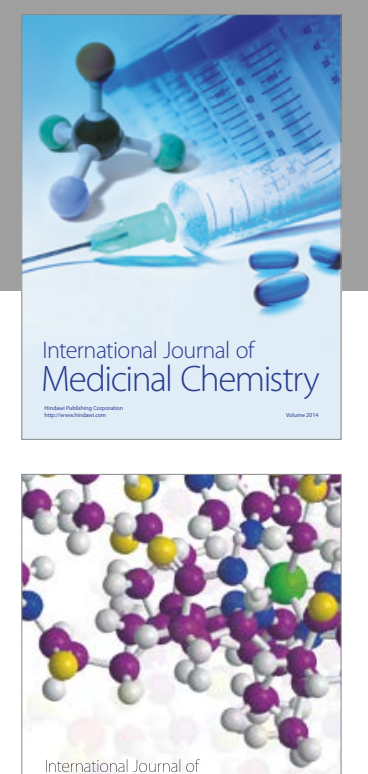

\section{Carbohydrate} Chemistry

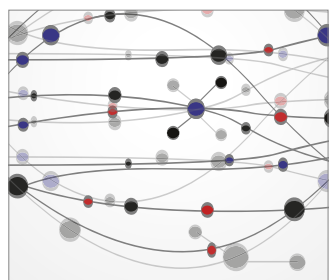

The Scientific

\section{World Journal}
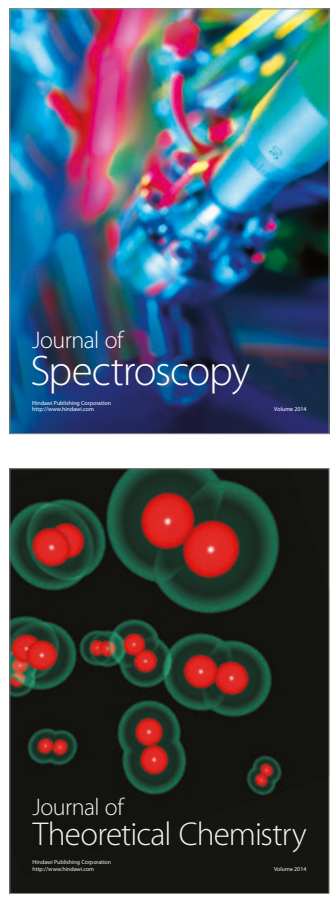
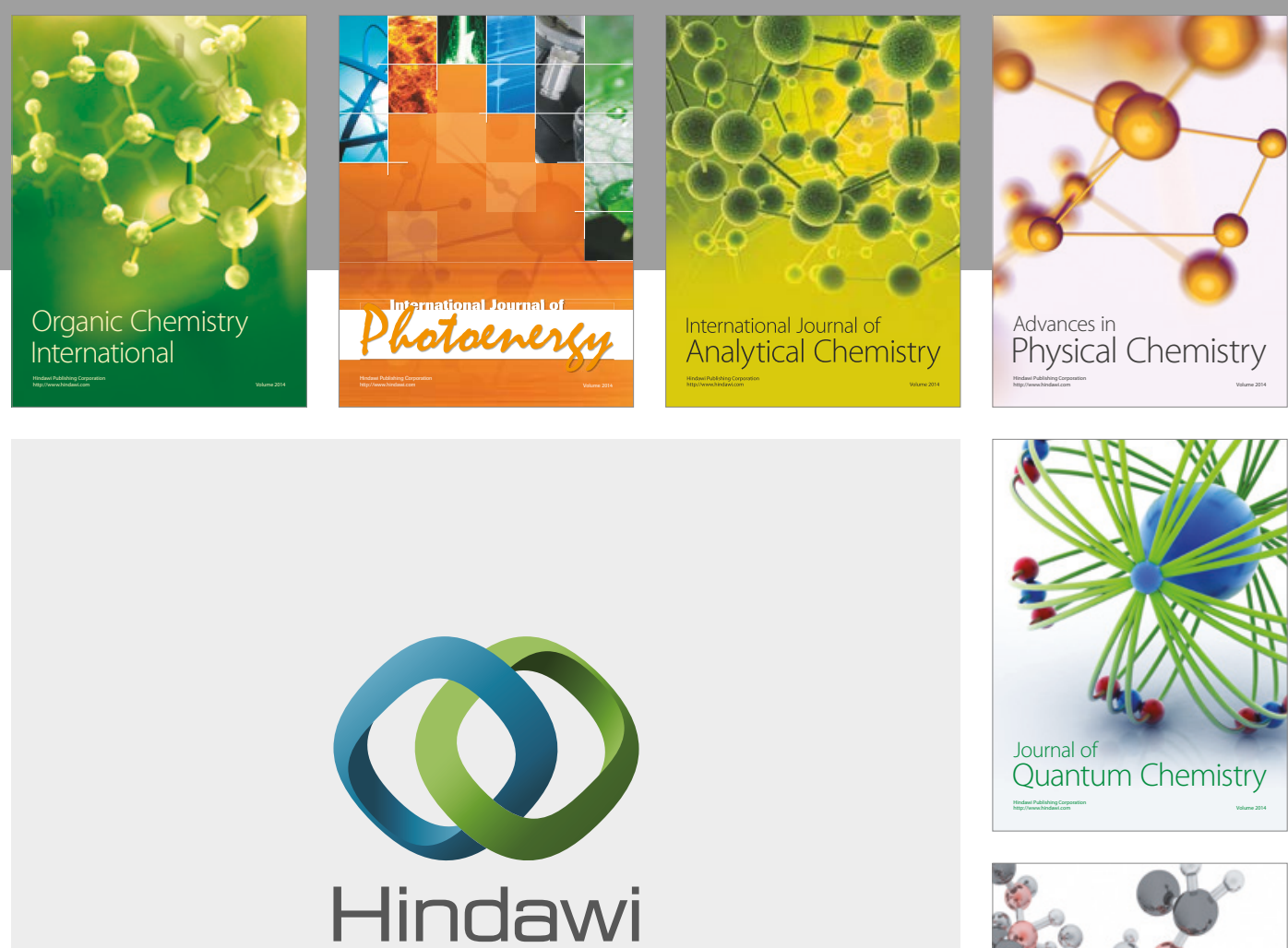

Submit your manuscripts at

http://www.hindawi.com
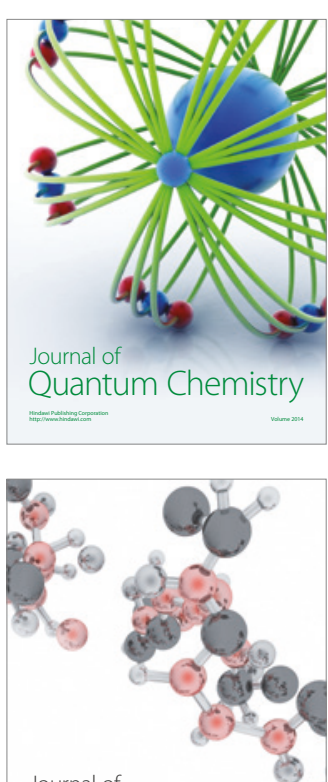

Analytical Methods

in Chemistry

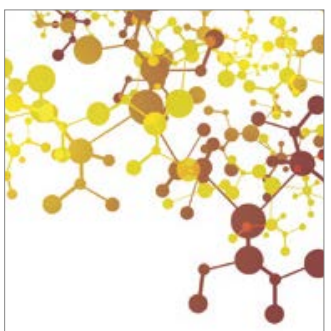

International Journal of

Inorganic Chemistry
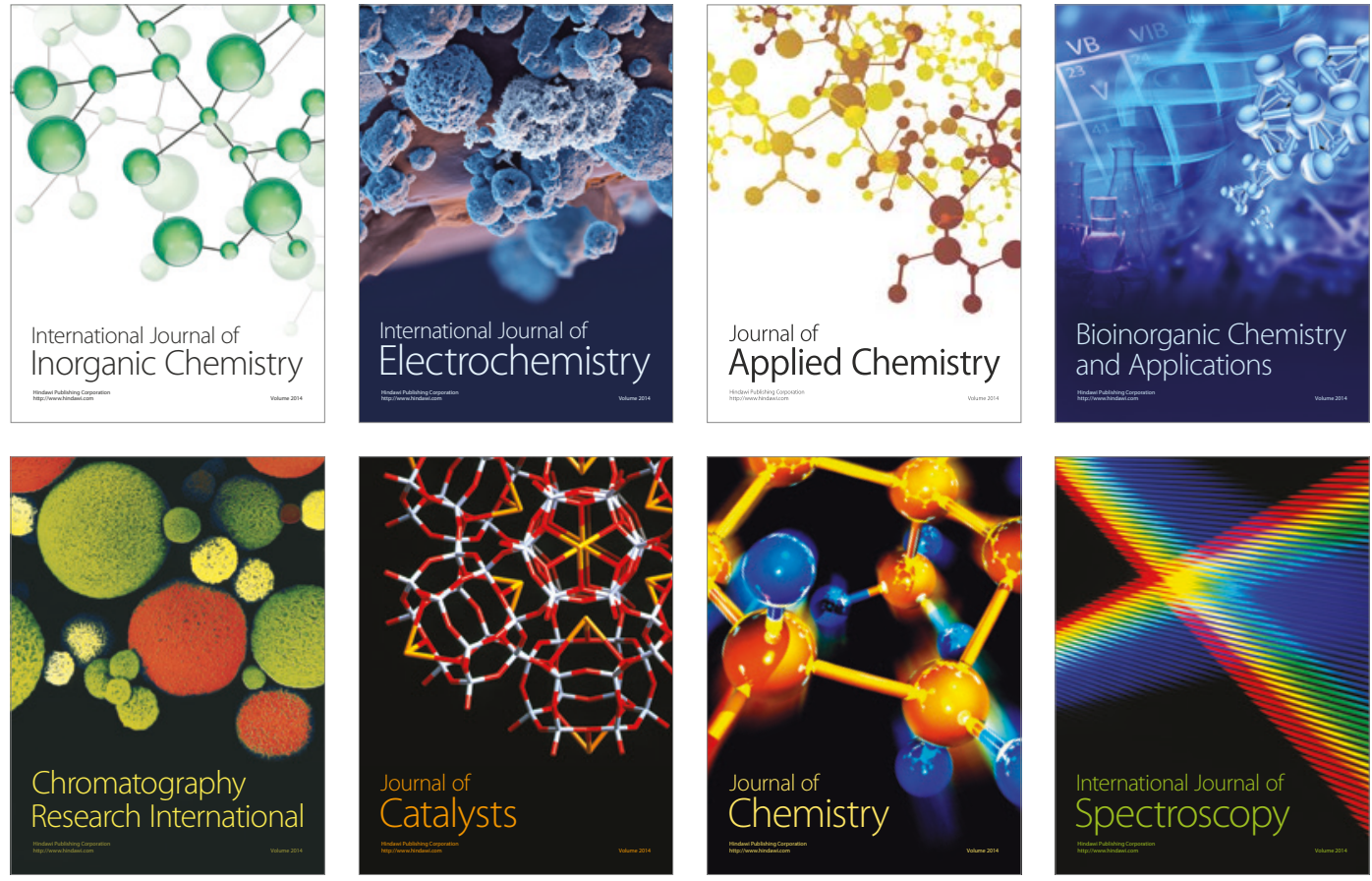

Applied Chemistry
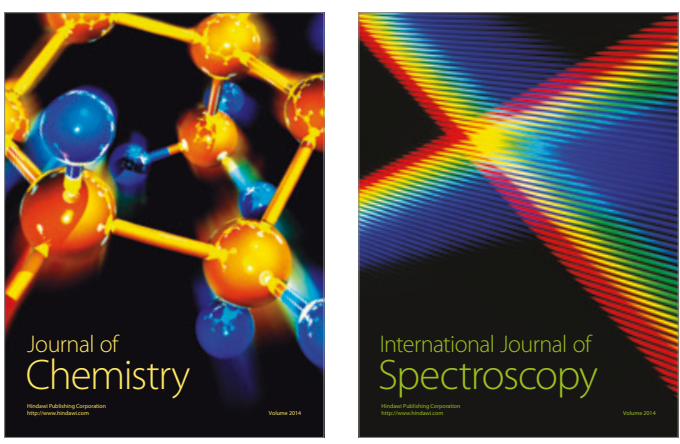